\title{
Top 20 POEMs of the Past 20 Years: A Survey of Practice-Changing Research for Family Physicians
}

\author{
Mark H. Ebell, $M D, M S^{1}$ \\ Henry C. Barry, MD, MS ${ }^{2}$ \\ Allen F. Shaugbnessy, PharmD, \\ $M E d^{3}$ \\ David C. Slawson, $M D^{4}$ \\ Nita Kulkarni, $M D^{5}$ \\ Linda Speer, $M D^{6}$ \\ ${ }^{1}$ College of Public Health, University of \\ Georgia, Athens, Georgia
}

${ }^{2}$ Department of Family Medicine, Michigan State University College of Human Medicine, East Lansing, Michigan

${ }^{3}$ Department of Family Medicine, Tufts University School of Medicine, Boston, Massachusetts

${ }^{4}$ Family Medicine, The University of North Carolina, Carolinas HealthCare System, Charlotte, North Carolina

${ }^{5}$ Feinberg School of Medicine, Northwestern University, Chicago, Illinois

${ }^{6}$ Department of Family Medicine, College of Medicine and Life Sciences, University of Toledo, Toledo, Ohio

Conflicts of interest: The authors are paid by Wiley-Blackwell, Inc to write the POEMs on a monthly basis.

\section{CORRESPONDING AUTHOR}

Mark H. Ebell MD, MS

125 Miller Hall

College of Public Health

UGA Health Sciences Campus

Athens, GA 30602

ebell@uga.edu

\begin{abstract}
POEMs (patient-oriented evidence that matters) are studies that address a relevant clinical question, demonstrate improved patient-oriented outcomes, and have the potential to change practice. For 20 years the authors of this article have reviewed more than 100 English language clinical journals monthly to identify POEMs in the medical literature relevant to primary care practice. This article identifies the POEMs in each of the last 20 years that were highest ranked for having recommended a major and persistent change in practice that year. They include POEMs that recommend a novel, effective intervention, a second group that recommends abandoning an ineffective practice, and a third group that recommends abandoning a potentially harmful practice. The top POEMs of the past 20 years illustrate the breadth of practice change in primary care and the need for family physicians to have a systematic approach to keeping up with the medical literature, such as that in POEMs, especially because many of these important articles did not appear in the primary care literature.
\end{abstract}

Ann Fam Med 2018;16:436-439. https://doi.org/10.1370/afm.2288.

\section{INTRODUCTION}

I n 1994, Slawson, Shaughnessy, and Bennett published the first of several articles that established the key concepts of "information mastery."1 Information mastery is an approach to evidence-based practice that helps physicians identify the most important evidence for practice. ${ }^{2}$ Traditional approaches to evidence-based practice emphasize evaluation of a study's internal validity and leave the issue of relevance and application to the end user. Information mastery emphasizes studies that address a relevant clinical question, demonstrate improved patient-oriented outcomes, and have the potential to change practice. An individual article that hits all 3 elements is called a POEM, or patient-oriented evidence that matters.

From 1994 to 1997, the authors generated a few POEMs each month that were published in The Journal of Family Practice. In late 1997, the publisher of the journal noted that POEMs were popular with readers and requested that the authors boost POEM production. In 1998, the authors of this article began to systematically review more than 100 clinical medical journals monthly to identify original research meeting the definition of a POEM (a current list of the journals is found in Supplemental Appendix 1, at http://www.annfammed.org/content/16/5/436/suppl/DC1). Each article is summarized by an independent primary care expert using a concise, structured format that identifies any methodologic strengths and weaknesses and provides a brief bottom-line recommendation for practice. The authors of POEMS (the "POETs") who have written these summaries are the authors of this article; Drs Ebell, Barry, and Slawson are family physicians; Dr Shaughnessy is a clinical pharmacologist; Dr Kulkarni is a hospital medicine specialist, and Dr Speer is a family physician and expert in women's health. Each POEM is also peer reviewed by the faculty and fellows of the University of Missouri Department of Family Medicine. After copy editing by our professional medical editor, Maria Vlasak, that 
month's POEMs are then e-mailed on a daily basis to subscribers of Essential Evidence Plus (http://www. essentialevidenceplus.com). Selected POEMs each month are also published in American Family Physician and are disseminated as a free audio podcast. Previous research has shown good interrater reliability for POEM selection, ${ }^{3}$ and work by others has shown the important impact of POEMs on learning, ${ }^{4}$ knowledge retention, ${ }^{5}$ and practice change. ${ }^{6-9}$

In the 20 years from 1998 to 2017, the authors identified 5,664 POEMs ( mean $=283 / \mathrm{y}$, range $=230$ 368). To celebrate the 20th anniversary of POEMs, we have selected the POEMs in each of the past 20 years that, in our judgment, have had the greatest impact on primary care practice. We also selected 4 runners-up for each year.

\section{METHODS}

The original group of 4 POETs (Slawson, Shaughnessy, Ebell, and Barry) were each assigned a 5-year period and reviewed all the POEMs written during those years. They then selected at least 5 POEMs for each year that they deemed most important in terms of recommending a major and persistent change in practice. These findings were compiled into a list 108 POEMs, stratified by year. Each POET then independently rated the candidate POEMs from 1 to 10 , where 10 represented "the most important POEM to recommend a major and persistent change in practice that year." The scale was otherwise not defined or anchored. Using a Delphi-like process, each POET was given the opportunity to change his or her ratings after reviewing the points assigned by the others. In the event of a tie, which occurred in 2014 and 2015 , the POETs voted for their favorite of the 2 finalists. When the same topic was selected in 2 separate years, the first appearance was used and the POEM with the second most votes was used for the year of that topic's second appearance. For example, articles estimating the overdiagnosis of breast cancer were chosen as the top POEM for both
2004 and 2006, so for 2006 the POEM with the second highest number of votes was used.

\section{RESULTS}

Table 1 displays the title and the original reference for each of the final 20 selected POEMs from 1998 to 2017. ${ }^{10-29}$ The top-scoring POEM for each year received between 34 and 39 points of a maximum of 40. The 100 top POEMs from 1998 to 2017 (5 from each year) are summarized in Supplemental Appendix 2 (http://www.annfammed.org/content/16/5/436/suppl/ DC1), including hyperlinks to the original POEM in Essential Evidence Plus.

\section{DISCUSSION}

This article summarizes the most important studies that recommended an important and persistent change
Table 1. Top POEM for Each Year From 1998 to 2017

\begin{tabular}{|c|c|c|}
\hline Year & Title of POEM & Reference \\
\hline 1998 & $\begin{array}{l}\text { Metformin is best for obese patients with type } 2 \\
\text { diabetes mellitus }\end{array}$ & $\begin{array}{l}\text { UK Prospective Diabetes Study } \\
\text { Group }\end{array}$ \\
\hline 1999 & $\beta$-Blockers are effective in heart failure & Lechat $\mathrm{P}$, et al ${ }^{11}$ \\
\hline 2000 & $\begin{array}{l}3 \text { Years between Papanicolaou tests are adequate } \\
\text { for many women }\end{array}$ & Sawaya GF, et al12 \\
\hline 2001 & $\begin{array}{l}\text { Managing heart rate and rhythm are similar for } \\
\text { atrial fibrillation }\end{array}$ & Hohnloser $\mathrm{SH}$, et al ${ }^{13}$ \\
\hline 2002 & Hormone replacement overall is not beneficial & $\begin{array}{l}\text { Writing Group for the Women's } \\
\text { Health Initiative Investigators }{ }^{14}\end{array}$ \\
\hline 2003 & Self-breast examination does not reduce mortality & Thomas DB, et al ${ }^{15}$ \\
\hline 2004 & Breast cancer screening results in overdiagnosis & Zahl P, et al ${ }^{16}$ \\
\hline 2005 & Vaccine prevents human papillomavirus infection & Harper DM, et al ${ }^{17}$ \\
\hline 2006 & $\begin{array}{l}\text { Delayed prescription for acute otitis media } \\
\text { reduces unnecessary antibiotics }\end{array}$ & Spiro DM, et al ${ }^{18}$ \\
\hline 2007 & $\begin{array}{l}\text { Home blood glucose monitoring is ineffective for } \\
\text { type } 2 \text { diabetes mellitus }\end{array}$ & Farmer $\mathrm{A}$, et al ${ }^{19}$ \\
\hline 2008 & $\begin{array}{l}\text { Intensive control of blood glucose in type } 2 \text { dia- } \\
\text { betes mellitus may be harmful }\end{array}$ & Gerstein $\mathrm{HC}$, et $\mathrm{al}^{20}$ \\
\hline 2009 & $\begin{array}{l}\text { Prostate-specific antigen screening does not } \\
\text { reduce mortality from prostate cancer }\end{array}$ & Andriole $\mathrm{GL}$, et $\mathrm{al}^{21}$ \\
\hline 2010 & $\begin{array}{l}\text { Statin + fenofibrate is no better than statin alone } \\
\text { in type } 2 \text { diabetes mellitus }\end{array}$ & The ACCORD Study Group 22 \\
\hline 2011 & $\begin{array}{l}\text { Rivaroxaban is similar to warfarin for patients } \\
\text { with nonvalvular atrial fibrillation }\end{array}$ & Patel $M R$, et $a^{23}$ \\
\hline 2012 & $\begin{array}{l}\text { Conservative therapy with antibiotics is an option } \\
\text { for early uncomplicated acute appendicitis }\end{array}$ & Varadhan $\mathrm{KK}$, et $\mathrm{al}^{24}$ \\
\hline 2013 & $\begin{array}{l}\text { Fasting is not necessary before measuring lipid } \\
\text { panels }\end{array}$ & Sidhu D and Naugler C25 \\
\hline 2014 & $\begin{array}{l}\text { Niacin does not improve clinical outcomes in } \\
\text { patients with vascular disease }\end{array}$ & $\begin{array}{l}\text { The HPS2-THRIVE Collaborative } \\
\text { Group, Landray MJ, et al }{ }^{26}\end{array}$ \\
\hline 2015 & $\begin{array}{l}\text { Steroids are beneficial as adjunctive treatment for } \\
\text { community-acquired pneumonia }\end{array}$ & Siemieniuk RAC, et al ${ }^{27}$ \\
\hline 2016 & $\begin{array}{l}\text { Active surveillance for localized prostate cancer: } \\
\text { no increased mortality, but higher rates of clini- } \\
\text { cal progression }\end{array}$ & Hamdy FC, et al ${ }^{28}$ \\
\hline 2017 & $\begin{array}{l}\text { Semaglutide reduces cardiovascular events in } \\
\text { high-risk patients with type } 2 \text { diabetes mellitus }\end{array}$ & Marso SP, et al 29 \\
\hline
\end{tabular}


in primary care practice in each of the years between 1998 and 2017. A review of these practice changers illustrate the breadth of primary care practice and the extent to which it has changed in the past 20 years. They can be broadly divided into 3 groups: (1) POEMs that recommend a novel, effective intervention, (2) those that recommend abandoning an ineffective practice, and (3) those that recommend abandoning a potentially harmful practice.

In the first group, a number of POEMs identified novel (at the time) treatments with the potential to improve patient-oriented outcomes. These treatments include $\beta$-blockers in heart failure, systemic corticosteroids for patients with community-acquired pneumonia, metformin as the drug of first choice for type 2 diabetes mellitus, antibiotics as the primary therapy for uncomplicated acute appendicitis, a vaccine to prevent human papillomavirus infection, semaglutide for high-risk patients with type 2 diabetes mellitus, delayed prescriptions to reduce antibiotic use, and the direct-acting oral anticoagulants for atrial fibrillation and venous thromboembolism.

Other POEMs recommended abandoning a practice that was widely practiced but ineffective, such as routinely recommending hormone replacement therapy for postmenopausal women, self-breast examination, an annual Papanicolaou test replaced by a longer interval between tests for most women, home blood glucose monitoring, fasting before a lipid panel blood test, the need for heart rhythm control in atrial fibrillation, and the use of fibrates and niacin for dyslipidemia.

Some POEMs identified practices that were not only ineffective but could lead to harm, including intensive blood glucose control for patients with type 2 diabetes mellitus, routine screening for prostate cancer with prostate-specific antigen, aggressive therapy for low-grade prostate cancer, and the harms of overdiagnosis that are increased with overly frequent or intensive screening for breast and prostate cancer.

When reviewing the full list (Supplemental Appendix 2), it is notable that some topics appeared more than once. These include increasing intervals between Papanicolaou tests (years 2000 and 2004), the use of delayed prescriptions to reduce antibiotic use (2002 and 2004), overdiagnosis of breast cancer (2004, 2006, and 2009), primary antibiotic therapy for acute appendicitis (2012 and 2015), aspirin to prevent preeclampsia in pregnancy $(2007,2014$, and 2017), and the lack of benefit from self-monitoring for type 2 diabetes mellitus in patients not using insulin (2007 and 2008). The duplication likely reflects the intense research interest on the topic and the importance of the study findings to primary care physicians. The POETs also believed that it was sometimes important to reinforce an uncomfortable or major change in practice using multiple studies in the hope of increasing the likelihood that it would be accepted into clinical practice.

Some POEMs served as a reminder of why primary care physicians need unbiased sources of credible information. A study's abstract is written by its authors and therefore may reflect their biases when interpreting the research. Studies often underemphasize harms and overemphasize benefit, ${ }^{30}$ report relative risks rather than absolute risk reduction or number needed to treat, or are industry-sponsored and therefore more likely than nonsponsored studies to report benefit. ${ }^{31}$ Thus, an objective and independent perspective is often beneficial. In some cases, variation in local practice patterns may result in overuse or underuse of therapies. After internal disagreement of the relevance of the results of a study of Unna boots (http://www. essentialevidenceplus.com/content/poem/30), we concluded that the disagreement was not related to the quality of the study, but rather to whether it would change practice. One POET had been using them for several years whereas another could not spell Unna!

We observed greater challenges in choosing the best POEMs in recent years, largely because it is difficult to know whether a 3-year-old study will withstand the test of time and the rigors of replication in realworld settings. This judgment is even more difficult because of the increasing amount of industry-sponsored research published in journals and the relatively small amount of public funding for research to support the study of real-world problems in real-world settings.

It would be difficult for any clinician in any specialty or discipline to read all of the journals publishing studies of potential importance, not to mention critically evaluate the validity of individual relevant articles. Clinicians regularly reading POEMs can confidently change practice with the knowledge that they are using the very latest, most relevant, and valid information to provide for the very best care for their patients. The current POEMs are oriented toward primary care, including obstetrics and general hospitalists. We hope to encourage the development of POEMs for other specialties and disciplines in medicine, as well as such other health care disciplines as dentistry and veterinary medicine.

To read or post commentaries in response to this article, see it online at http://www.AnnFamMed.org/content/16/5/436.

Submitted January 18, 2018; submitted, revised, April 30, 2018; accepted May 17, 2018.

Key words: POEM; acute illness; prevention; promotion of health; women's health; chronic disease, education

Funding support: Wiley-Blackwell, Inc, provided financial support to write the POEMs on a monthly basis. 
Disclaimer: The authors have full editorial control and oversight over the selection and writing of POEMs.

Acknowledgments: The authors would like to acknowledge with deep gratitude the contribution Maria Vlasak, who has edited, corrected, and improved every POEM ever written, as well as the faculty and fellows of the University of Missouri Department of Family Medicine for 20 years of thorough and thoughtful peer review, and Keith Hume, who helped us disseminate the concept to a broader audience.

- Supplementary materials: Available at http://www.AnnFamMed. org/content/16/5/436/suppl/DC1/.

\section{References}

1. Slawson DC, Shaughnessy AF, Bennett JH. Becoming a medical information master: feeling good about not knowing everything. J Fam Pract. 1994;38(5):505-513.

2. Slawson DC, Shaughnessy AF, Ebell MH, Barry HC. Mastering medical information and the role of POEMs-Patient-Oriented Evidence that Matters. J Fam Pract. 1997;45(3):195-196.

3. Ebell MH, Barry HC, Slawson DC, Shaughnessy AF. Finding POEMs in the medical literature. J Fam Pract. 1999:48(5):350-355.

4. Leung GM, Johnston JM, Tin KY, et al. Randomised controlled trial of clinical decision support tools to improve learning of evidence based medicine in medical students. BMJ. 2003;327(7423):1090.

5. Katerndahl DA, Ferrer RL. Randomized trial of the effect of research design and publication characteristics on physician change. Prim Care Companion J Clin Psychiatry. 2006;8(1):32-38.

6. Geyman JP. POEMs as a paradigm shift in teaching, learning, and clinical practice. Patient-Oriented Evidence that Matters. J Fam Pract. 1999;48(5):343-344.

7. Grad RM, Pluye P, Meng Y, Segal B, Tamblyn R. Assessing the impact of clinical information-retrieval technology in a family practice residency. J Eval Clin Pract. 2005;11(6):576-586.

8. Grad RM, Pluye P, Mercer J, et al. Impact of research-based synopses delivered as daily e-mail: a prospective observational study. J Am Med Inform Assoc. 2008;15(2):240-245.

9. Grad R, Pluye P, Johnson-Lafleur J, et al. Do family physicians retrieve synopses of clinical research previously read as email alerts? J Med Internet Res. 2011;13(4):e101.

10. UK Prospective Diabetes Study (UKPDS) Group. Effect of intensive blood-glucose control with metformin on complications in overweight patients with type 2 diabetes (UKPDS 34). Lancet. 1998; 352(9131):854-865.

11. Lechat P, Packer M, Chalon S, Cucherat M, Arab T, Boissel J-P. Clinical effects of beta-adrenergic blockade in chronic heart failure: a meta-analysis of double-blind, placebo-controlled, randomized trials. Circulation. 1998;98(12):1184-1191.

12. Sawaya GF, Kerlikowske K, Lee NC, Gildengorin G, Washington AE. Frequency of cervical smear abnormalities within 3 years of normal cytology. Obstet Gynecol. 2000;96(2):219-223.

13. Hohnloser SH, Kuck KH, Lilienthal J. Rhythm or rate control in atrial fibrillation-Pharmacological Intervention in Atrial Fibrillation (PIAF): a randomised trial. Lancet. 2000;356(9244):1789-1794.

14. Rossouw JE, Anderson GL, Prentice RL, et al; Writing Group for the Women's Health Initiative Investigators. Risks and benefits of estrogen plus progestin in healthy postmenopausal women: principal results from the Women's Health Initiative randomized controlled trial. JAMA. 2002;288(3):321-333.
15. Thomas DB, Gao DL, Ray RM, et al. Randomized trial of breast self-examination in Shanghai: final results. J Natl Cancer Inst. 2002; 94(19):1445-1457.

16. Zahl PH, Strand BH, Maehlen J. Incidence of breast cancer in Norway and Sweden during introduction of nationwide screening: prospective cohort study. BMJ. 2004;328(7445):921-924.

17. Harper DM, Franco EL, Wheeler C, et al; GlaxoSmithKline HPV Vaccine Study Group. Efficacy of a bivalent L1 virus-like particle vaccine in prevention of infection with human papillomavirus types 16 and 18 in young women: a randomised controlled trial. Lancet. 2004; 364(9447):1757-1765.

18. Spiro DM, Tay KY, Arnold DH, Dziura JD, Baker MD, Shapiro ED. Wait-and-see prescription for the treatment of acute otitis media: a randomized controlled trial. JAMA. 2006;296(10):1235-1241.

19. Farmer A, Wade A, Goyder E, et al. Impact of self monitoring of blood glucose in the management of patients with non-insulin treated diabetes: open parallel group randomised trial. BMJ. 2007; 335(7611):132.

20. Gerstein HC, Miller ME, Byington RP, et al; Action to Control Cardiovascular Risk in Diabetes Study Group. Effects of intensive glucose lowering in type 2 diabetes. N Engl J Med. 2008;358(24): 2545-2559.

21. Andriole GL, Crawford ED, Grubb RL III, et al; PLCO Project Team. Mortality results from a randomized prostate-cancer screening trial. N Engl J Med. 2009;360(13):1310-1319.

22. Ginsberg HN, Elam MB, Lovato LC, et al; ACCORD Study Group. Effects of combination lipid therapy in type 2 diabetes mellitus. $N$ Engl J Med. 2010;362(17):1563-1574.

23. Patel MR, Mahaffey KW, Garg J, et al; ROCKET AF Investigators. Rivaroxaban versus warfarin in nonvalvular atrial fibrillation. $N$ Engl J Med. 2011;365(10):883-891.

24. Varadhan KK, Neal KR, Lobo DN. Safety and efficacy of antibiotics compared with appendicectomy for treatment of uncomplicated acute appendicitis: meta-analysis of randomised controlled trials. BMJ. 2012;344:e2156.

25. Sidhu D, Naugler C. Fasting time and lipid levels in a communitybased population: a cross-sectional study. Arch Intern Med. 2012; 172(22):1707-1710.

26. Landray MJ, Haynes R, Hopewell JC, et al; HPS2-THRIVE Collaborative Group. Effects of extended-release niacin with laropiprant in high-risk patients. N Engl J Med. 2014;371(3):203-212.

27. Siemieniuk RAC, Meade MO, Alonso-Coello P, et al. Corticosteroid therapy for patients hospitalized with community-acquired pneumonia: a systematic review and meta-analysis. Ann Intern Med. 2015; 163(7):519-528.

28. Hamdy FC, Donovan JL, Lane JA, et al; Protect Study Group. 10-Year outcomes after monitoring, surgery, or radiotherapy for localized prostate cancer. N Engl J Med. 2016;375(15):1415-1424.

29. Marso SP, Bain SC, Consoli A, et al; SUSTAIN-6 Investigators. Semaglutide and cardiovascular outcomes in patients with type 2 diabetes. N Engl J Med. 2016;375(19):1834-1844.

30. Golder S, Loke YK, Wright K, Norman G. Reporting of adverse events in published and unpublished studies of health care interventions: a systematic review. PLoS Med. 2016;13(9). e1002127.

31. Lexchin J, Bero LA, Djulbegovic B, Clark O. Pharmaceutical industry sponsorship and research outcome and quality: systematic review. BMJ. 2003;326(7400):1167-1170. 